\title{
Structure and Performance-Related Changes in Puberty in a Group of Ice Hockey Players
}

\author{
Jakub Krajňák
}

Masaryk University

\begin{abstract}
The article deals with structure and performance-related changes occurring in the beginning of puberty in relation to ice-hockey players of the older pupil category. 20 male players born in 2005 and in 2006 of corresponding biological age underwent measuring of their somatic parameters, balance and specific performance on ice. To evaluate the maturity age, the Roche-Wainer-Thissen method was used; moreover, the Star excursion balance test (SEBT) was used to assess the balance and the Illinois agility test (IAT) without a puck was used to assess the performance on ice.

The results show that players born in 2005 show bigger structural changes in comparison with those born in 2006; nevertheless, no differences in somatotypology were found. As far as performance is concerned, the players born in 2005 were faster in the IAT while those born in 2006 displayed bigger reaches in SEBT - specifically in the anteromedial (AM), medial (M), posteromedial (PM), posterior $(P)$, posterolateral $(P L)$, anterolateral $(A L)$ direction and the composite score (COMP). These findings strongly indicate that IAT depends on the production of strength which was bigger due to the structural changes. The SEBT results of the players born in 2005 may have been influenced by the puberty spurt during which adolescents' coordination stagnates due to a worsened postural control. The growth of body proportionality may have led to lever changes and to ineffective motor control while dealing with a new motor task as well. Another reason for the above-mentioned may also be muscle shortening.
\end{abstract}

Keywords: puberty, maturity age, ice hockey, Star excursion balance test, Illinois agility test

\section{INTRODUCTION}

Puberty begins in the older school age during which functional and structural changes occur. The state of having reached puberty cannot be deduced from the chronological age; e.g. two boys of the same chronological age and different maturity age can reach puberty even two years apart from each other (Dimock, 1935). Structural changes tend to correlate with maturity age rather than with chronological age as puberty can be gone through in a large span of chronological ages (Sugden \& Wade, 2013). Puberty causes the increased production of growth hormones supporting the production of thyroxine and sex hormones in the hypophysis which leads to the bodily growth accompanied by changes in bones, tissues and metabolism (Tanner, 1990). It leads to the peak height velocity which occurs in the $14^{\text {th }}$ year of age of boys (Jones, 1946). Dimock (1935) tested motor ability tests by Brace test among boys ages $12-16$. The overall results of the test indicate worsening of progress in the $14^{\text {th }}$ and $15^{\text {th }}$ year of age. He explains this by saying that swiftlygrowing adolescents are characterised by partial clumsiness due to the growth of bones and the 
body which has grown out of their muscle control. Espenschade et al. (1953) confirm the decrease of dynamic balance in the beam walking test manifesting itself by a considerable "adolescent lag".

Balance is a component of physical condition which is essential for the performance and the prevention of injuries. It is an ability to maintain the body in a balanced condition even during tense situations and in changeable environment (Lehnert et al., 2014). A notion closely related to balance is the level of proprioception in connection with orientation skills (Perič \& Dovalil, 2010). Besides the everyday life, balance (both static and dynamic) is made use of especially in combat sports, artistic and rhythmic gymnastics, figure skating, skiing, and team sports. To assess the level of dynamic balance, the Star Excursion Balance Test (SEBT) was selected. Its simplicity, low cost and applicability both in a laboratory as well as on a sports ground were the crucial attributes which led to the selection of this test.

Agility movements can be defined as rapid whole-body movements that require single or multiple changes in velocity or direction in response to an external stimulus (Sands, Wurth, \& Hewitt, 2012). Agility training includes multiple modalities including strength and power, sprint, specific agility, balance and coordination as well as flexibility training. It can be enhanced by many agility drills (Ratamess, 2012). To assess the agility level the Illinois agility test was selected.

\section{METHODS}

The tests were conducted on male ice hockey youth of HC Kometa Brno born in years 2005 and $2006(\mathrm{n}=35)$. During a season, they usually train on-ice for $4-5$ hours per week and 2-3 hours per week off-ice. In most cases, they have 1-2 matches per week. The tests were applied during the off-season from June 2019 to September 2019.

The subject had a warm-up for 10-15 minutes consisting of running and dynamic stretching. After the warm-up, the subject underwent a SEBT test (figure 1). The subjects were instructed about the technique as well as to undergo the test in usual off-ice sport clothes (shorts, shoes) and with a hockey stick. Each subject could take the test once. The standing limb had to stay in the middle of a cross with no move to a side and no raising the heel. The hockey stick could be held either in one hand or in both hands but its contact with the ground was considered a failed attempt. If the subject made a mistake, he was asked to repeat the same direction with correction.

After completing the SEBT test, he went on to prepare for an on-ice training. Before the on-ice training, he underwent the agility test. For the purpose of on-ice testing, the Illinois agility test without a puck was chosen (figure 2). This modification is more typical for ice hockey players. It is used by the Czech Ice Hockey Association to test young Czech ice hockey players (Český hokej, 2017). After a sound signal, the subjects were asked to skate as fast as possible on the track. An extra attempt was allowed in case of a mistake. 

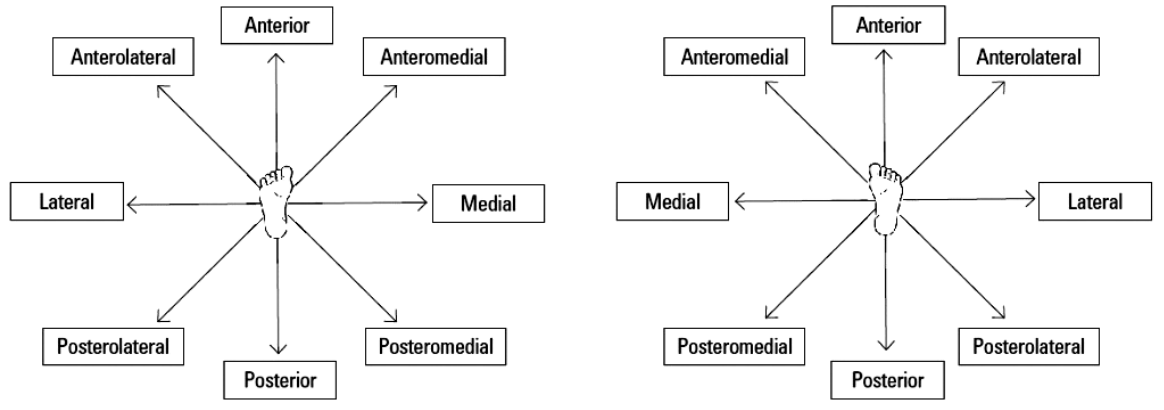

Figure 1 Star excursion balance test
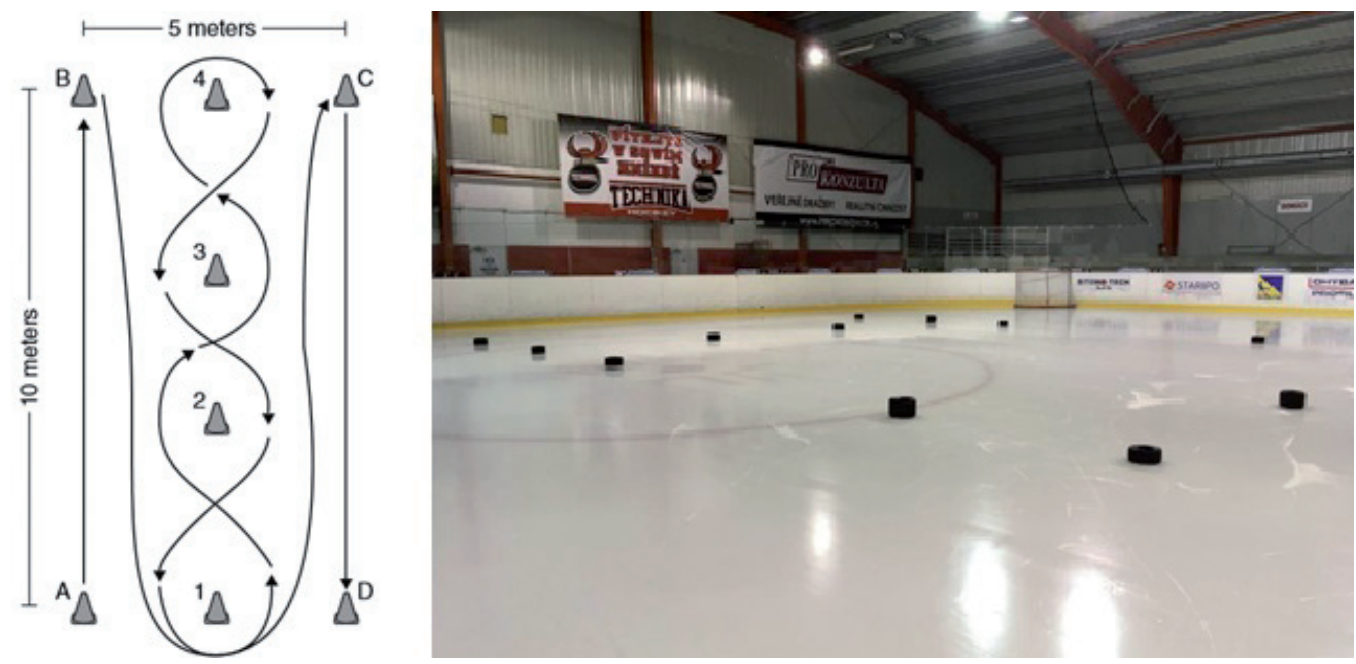

Figure 2 Illinois agility test on-ice

Finally, after the training the anthropometric data were measured and the subject was questioned about his personal information (table 1). The obtained data were used to determine the somatotype with the use of the Heath-Carter protocol (Carter, 2002). Maturity age was calculated using the Roche-Wainer-Thissen method (RWT) which predicts the body height of an adult at the age of 18 (Roche \& Davila, 1972). It can be determined from the mid-parent stature (MPS), skeletal age (SA), present weight (W) and recumbent length (RL). If the recumbent length value is unknown, it can be calculated from the present stature $+1.25 \mathrm{~cm}$. Due to the limited possibilities of determining the SA the modification of the RWT method for adult stature was used where SA is replaced by chronological age (CA). The constants used to determine the adult stature prediction are given in Table XXVII (Roche, Wainer, \& Thissen, 1975).

The Roche-Wainer-Thissen method of the adult stature prediction:

Predicted adult stature $=R L \times \beta R L-W \times \beta W+M P S \times \beta M P S-C A \times \beta S A+\beta 0$ 
The results are subsequently converted to the relative statures estimated without the SA:

\section{(Present stature $\div$ predicted adult stature) $\times 100$}

Relative statures were compared to the FELS Longitudinal study which measured child growth and development since 1927 (Khamis \& Roche, 1994). Using FELS, the maturity age (MA) was determined by half-years. Maturity age higher than 14 was labelled as $14+$.

Tab. 1: Data for predicting maturity age

\begin{tabular}{|c|c|c|c|c|c|c|c|c|c|c|}
\hline \multirow{2}{*}{ Number } & \multirow{2}{*}{$\begin{array}{c}\text { Year } \\
\text { of } \\
\text { birth }\end{array}$} & \multirow{2}{*}{ Position } & \multirow{2}{*}{$\begin{array}{c}\mathrm{RL} \\
(\mathrm{cm})\end{array}$} & \multirow{2}{*}{$\begin{array}{c}\text { Weight } \\
\text { (kg) }\end{array}$} & \multicolumn{2}{|c|}{ Age } & \multirow{2}{*}{$\begin{array}{l}\text { MPS } \\
(\mathrm{cm})\end{array}$} & \multirow{2}{*}{$\begin{array}{l}\text { RWT } \\
(\mathrm{cm})\end{array}$} & \multirow{2}{*}{$\begin{array}{c}\text { RWT } \\
(\%)\end{array}$} & \multirow{2}{*}{ MA } \\
\hline & & & & & year & month & & & & \\
\hline 1 & 2006 & $\mathrm{D}$ & 168.25 & 58 & 12 & 10 & 168.5 & 185.3 & 90.8 & 14.0 \\
\hline 2 & 2005 & $\mathrm{D}$ & 178.25 & 72 & 13 & 9 & 170 & 186.8 & 95.4 & $14+$ \\
\hline 3 & 2006 & $\mathrm{~F}$ & 165.25 & 54 & 12 & 8 & 179 & 188.5 & 87.7 & 13.0 \\
\hline 4 & 2005 & $\mathrm{~F}$ & 164.25 & 46 & 14 & 4 & 177.5 & 180.4 & 91.0 & 14.0 \\
\hline 5 & 2005 & $\mathrm{~F}$ & 168.25 & 51 & 14 & 1 & 178.5 & 184.4 & 91.2 & 14.0 \\
\hline 6 & 2005 & $\mathrm{D}$ & 168.25 & 58 & 14 & 2 & 169 & 178.8 & 94.1 & 14.0 \\
\hline 7 & 2006 & $\mathrm{D}$ & 155.25 & 42 & 13 & 1 & 172.5 & 178.1 & 87.2 & 13.0 \\
\hline 8 & 2006 & $\mathrm{~F}$ & 166.25 & 49 & 12 & 10 & 180 & 189.6 & 87.7 & 13.0 \\
\hline 9 & 2006 & $\mathrm{~F}$ & 167.25 & 59 & 13 & 4 & 170.5 & 182.5 & 91.6 & 14.0 \\
\hline 10 & 2006 & $\mathrm{D}$ & 167.25 & 63 & 13 & 4 & 166 & 180.0 & 92.9 & 14.0 \\
\hline 11 & 2006 & $\mathrm{~F}$ & 156.25 & 41 & 12 & 8 & 169 & 179.2 & 87.2 & 13.0 \\
\hline 12 & 2006 & $\mathrm{~F}$ & 158.25 & 44 & 13 & 5 & 178.5 & 181.1 & 87.4 & 13.0 \\
\hline 13 & 2006 & $\mathrm{D}$ & 150.25 & 37 & 12 & 10 & 171.5 & 175.2 & 85.7 & 12.0 \\
\hline 14 & 2006 & $\mathrm{D}$ & 148.25 & 43 & 12 & 9 & 166 & 170.2 & 87.1 & 13.0 \\
\hline 15 & 2005 & G & 178.25 & 63 & 13 & 11 & 180 & 191.4 & 93.1 & 14.0 \\
\hline 16 & 2005 & $\mathrm{~F}$ & 159.25 & 57 & 14 & 1 & 173.5 & 175.0 & 91.0 & 14.0 \\
\hline 17 & 2006 & $\mathrm{~F}$ & 170.25 & 50 & 13 & 3 & 178 & 189.5 & 89.9 & 13.0 \\
\hline 18 & 2006 & $\mathrm{~F}$ & 165.25 & 48 & 13 & 3 & 176 & 185.1 & 89.3 & 14.0 \\
\hline 19 & 2005 & $\mathrm{D}$ & 172.25 & 54 & 13 & 11 & 182 & 189.1 & 91.1 & 13.0 \\
\hline 20 & 2006 & G & 169.25 & 49 & 12 & 10 & 172 & 188.7 & 89.7 & 13.0 \\
\hline 21 & 2005 & $\mathrm{~F}$ & 183.25 & 65 & 14 & 4 & 181 & 192.7 & 95.1 & $14+$ \\
\hline 22 & 2005 & $\mathrm{~F}$ & 177.25 & 57 & 13 & 9 & 179.5 & 191.8 & 92.4 & 14.0 \\
\hline 23 & 2005 & $\mathrm{~F}$ & 163.25 & 50 & 13 & 10 & 173.5 & 179.9 & 90.7 & 14.0 \\
\hline 24 & 2006 & $\mathrm{~F}$ & 157.25 & 46 & 12 & 11 & 174 & 180.2 & 87.3 & 13.0 \\
\hline 25 & 2005 & $\mathrm{~F}$ & 167.25 & 52 & 14 & 2 & 174.5 & 181.0 & 92.4 & 14.0 \\
\hline 26 & 2006 & F & 156.25 & 46 & 12 & 10 & 175 & 180.0 & 86.8 & 12.5 \\
\hline 27 & 2006 & $\mathrm{~F}$ & 156.25 & 52 & 12 & 7 & 171 & 178.3 & 87.6 & 13.0 \\
\hline 28 & 2006 & $\mathrm{D}$ & 160.25 & 50 & 12 & 11 & 169 & 180.4 & 88.8 & 13.0 \\
\hline 29 & 2005 & G & 159.25 & 46 & 13 & 7 & 173 & 178.6 & 89.1 & 13.0 \\
\hline 30 & 2005 & $\mathrm{D}$ & 174.25 & 85 & 13 & 8 & 179 & 184.9 & 94.3 & 14.0 \\
\hline 31 & 2005 & $\mathrm{D}$ & 172.25 & 62 & 13 & 10 & 172 & 183.8 & 93.7 & 14.0 \\
\hline 32 & 2005 & $\mathrm{~F}$ & 169.25 & 63 & 13 & 11 & 176 & 183.5 & 92.2 & 14.0 \\
\hline 33 & 2006 & $\mathrm{D}$ & 154.25 & 42 & 12 & 8 & 174.5 & 179.7 & 85.8 & 12.0 \\
\hline 34 & 2006 & $\mathrm{~F}$ & 173.25 & 66 & 13 & 4 & 173.5 & 187.0 & 92.7 & 14.0 \\
\hline 35 & 2006 & $\mathrm{D}$ & 168.25 & 62 & 13 & 4 & 172.5 & 183.4 & 91.8 & 14.0 \\
\hline
\end{tabular}




\section{RESULTS}

The result of all the participants $(n=35)$ show that the biological age of 20 of them corresponds with their year of birth ( $\mathrm{n}=10$ both groups). Goalkeepers were eliminated from the measuring in order to increase the homogeneity of the sample. The obtained anthropometric data along with the values obtained from the exercise tests are given in table 2.

Tab. 2: The mean values and SD of general data about groups, anthropometric measuring, somatotype and performance tests (IAT and W170) with Cohen's d

\begin{tabular}{|c|c|c|c|c|c|}
\hline & \multicolumn{2}{|c|}{$2006(n=10)$} & \multicolumn{2}{|c|}{$2005(n=10)$} & \multirow{2}{*}{ Cohen's d } \\
\hline & Mean & SD & Mean & SD & \\
\hline Age & 12.87 & 0.24 & 13.95 & 0.18 & $5.09^{*}$ \\
\hline Height $(\mathrm{cm})$ & 158.10 & 6.06 & 167.10 & 5.07 & $1.61^{\star}$ \\
\hline Weight (kg) & 47.10 & 4.28 & 58.10 & 10.32 & $1.39^{*}$ \\
\hline Length of limb (cm) & 82.65 & 3.55 & 86.35 & 3.15 & $1.10^{*}$ \\
\hline Body fat (\%) & 13.06 & 3.92 & 11.65 & 5.13 & 0.31 \\
\hline W170 (W/kg) & 2.76 & 0.27 & 3.10 & 0.18 & $1.48^{\star}$ \\
\hline Illinois (s) & 17.62 & 0.92 & 16.72 & 0.55 & $1.19^{*}$ \\
\hline \multicolumn{6}{|l|}{ Anthropometry } \\
\hline Suprailiacal skin fold (mm) & 5.10 & 0.94 & 5.90 & 2.12 & 0.49 \\
\hline Subscapular skin fold (mm) & 5.50 & 0.81 & 6.50 & 1.32 & $0.91^{\star}$ \\
\hline Skin fold of thigh (mm) & 10.50 & 1.86 & 9.40 & 1.44 & 0.66 \\
\hline Skin fold of calf (mm) & 11.95 & 2.13 & 10.65 & 1.68 & 0.68 \\
\hline Skin fold of triceps (mm) & 8.80 & 1.54 & 7.80 & 1.60 & 0.64 \\
\hline Skin fold of biceps (mm) & 4.20 & 0.60 & 4.50 & 0.81 & 0.42 \\
\hline Circuit of thigh $(\mathrm{cm})$ & 44.60 & 2.58 & 47.10 & 5.26 & 0.60 \\
\hline Circuit of calf $(\mathrm{cm})$ & 32.20 & 1.60 & 33.70 & 3.00 & 0.62 \\
\hline Circuit of arm $(\mathrm{cm})$ & 25.35 & 1.14 & 27.70 & 1.75 & $1.59^{\star}$ \\
\hline Humerus width (mm) & 64.40 & 1.80 & 67.10 & 3.62 & $0.94^{*}$ \\
\hline Femur width (mm) & 90.50 & 4.70 & 95.80 & 5.40 & $1.05^{\star}$ \\
\hline \multicolumn{6}{|l|}{ Somatotype } \\
\hline Endomorphy & 2.00 & 0.45 & 1.95 & 0.65 & 0.09 \\
\hline Mesomorphy & 4.45 & 1.00 & 4.40 & 0.88 & 0.05 \\
\hline Ectomorphy & 3.55 & 0.99 & 3.20 & 1.35 & 0.30 \\
\hline
\end{tabular}

* Values with large effect size

Table 3 contains the values from SEBT which were normalized by the length of the lower limbs and composite score was calculated as a sum of the distances in all the directions divided by the number of directions. 
Tab. 3: The mean values and SD of 2006 and 2005 groups with SEBT score and Cohen's $d$

\begin{tabular}{|c|c|c|c|c|c|c|}
\hline \multirow{2}{*}{ SEBT directions } & \multirow{2}{*}{$\begin{array}{l}\text { Standing } \\
\text { limb }\end{array}$} & \multicolumn{2}{|c|}{$2006(n=10)$} & \multicolumn{2}{|c|}{$2005(\mathrm{n}=10)$} & \multirow{2}{*}{ Cohen's $d$} \\
\hline & & Mean & $\mathrm{SD}$ & Mean & SD & \\
\hline \multirow{2}{*}{ Anterior } & left & 91.23 & 6.15 & 86.87 & 5.27 & 0.76 \\
\hline & right & 90.12 & 6.44 & 85.64 & 4.73 & 0.79 \\
\hline \multirow{2}{*}{ Anteromedial } & left & 98.40 & 5.43 & 92.98 & 4.40 & $1.10^{*}$ \\
\hline & right & 101.41 & 7.65 & 94.07 & 6.35 & $1.04^{*}$ \\
\hline \multirow{2}{*}{ Medial } & left & 102.44 & 9.39 & 96.18 & 7.83 & 0.72 \\
\hline & right & 105.33 & 6.86 & 95.57 & 9.36 & $1.19^{*}$ \\
\hline \multirow{2}{*}{ Posteromedial } & left & 108.06 & 7.72 & 99.59 & 10.52 & $0.92^{\star}$ \\
\hline & right & 109.88 & 6.77 & 102.47 & 7.78 & $1.02^{*}$ \\
\hline \multirow{2}{*}{ Posterior } & left & 112.10 & 6.89 & 103.15 & 8.30 & $1.17^{\star}$ \\
\hline & right & 110.62 & 8.28 & 106.97 & 5.23 & 0.53 \\
\hline \multirow{2}{*}{ Posterolateral } & left & 103.09 & 7.30 & 97.50 & 5.41 & $0.87^{\star}$ \\
\hline & right & 101.57 & 6.50 & 97.47 & 6.32 & 0.64 \\
\hline \multirow{2}{*}{ Lateral } & left & 86.72 & 7.61 & 89.07 & 9.37 & 0.28 \\
\hline & right & 90.09 & 8.43 & 85.87 & 8.32 & 0.50 \\
\hline \multirow{2}{*}{ Anterolateral } & left & 80.04 & 5.73 & 73.85 & 5.63 & $1.09^{*}$ \\
\hline & right & 80.37 & 5.66 & 73.50 & 6.03 & $1.17^{\star}$ \\
\hline \multirow{2}{*}{ Composite score } & left & 97.76 & 4.51 & 92.40 & 4.84 & $1.15^{\star}$ \\
\hline & right & 98.67 & 4.89 & 92.69 & 5.02 & $1.21^{*}$ \\
\hline
\end{tabular}

* Values with large effect size

\section{DISCUSSION}

The obtained results show that as far as somatotypes are concerned, the players born in 2005 are better-built than the players born in 2006; this may be caused by the puberty spurt. Even though somatotypology in accordance with the Heath-Carter protocol did not show any somatotyperelated differences between the groups of players, the variables necessary to determine a somatotype are of great substantive significance (subscapular skin fold: Cohen's $d=0.91$, large; circuit of arm: Cohen's $d=1.59$, large; humerus width: Cohen's $d=0.94$, large; femur width: Cohen's $\mathrm{d}=1.05$, large).

The players born in 2005 also achieved better results in the IAT from the point of view of performance. The same result was achieved also in the W170 test in which the players born in 2005 achieved better relative values than the players born in 2006 (3.10 W/kg vs. 2.76; Cohen's $\mathrm{d}=1.48$, large). As Jones (1946) noted, the growth of strength tends to begin approximately at the skeletal age of 14 years, which corresponds with the result.

The players born in 2006 were more successful concerning dynamic balance; they achieved substantive significance with large effect in AM, M, PM, AL a COMP in relation to both lower limbs and only in relation to the standing left lower limb in the P and PL directions. It can be caused by the adolescent lag during which the linearity of the progress is disrupted which manifests itself in sudden changes of postural control; coordination subsequently stabilizes in a later stage of puberty (Dimock, 1935). Moreover, it can be caused by the puberty spurt during which the musculoskeletal system develops and manifests itself by the imbalance between strength and flexibility (Shanmugam \& Maffulli, 2008) which leads to a worse performance in SEBT (Gribble, Hertel, \& Plisky, 2012). 
IAT is considered to be a versatile test influenced by several skills: agility, speed, strength and coordination. The players born in 2005 not having reached better results in dynamic balance than the players born in 2006 could be caused by the fact that ice skating is an acquired skill while SEBT is a new motor task. It could also be caused by the fact that undergoing IAT depends mainly on strength skills rather than on coordination skills.

\section{CONCLUSION}

The aim of the study was to discover structural and performance-related differences in relation to older pupils during the puberty spurt. As the period during which the puberty spurt can begin is too broad, the chronological age is insufficient to determine the maturity. On the other hand, the maturity age is determined by somatic parameters which indicate the stage of development of a young sportsman more precisely. The research focused on the differences between prepubescent and pubescent players, which is why biologically delayed as well as accelerated players were eliminated from the research.

From the total number of players $(\mathrm{n}=35)$ only forwards and defensemen of the abovementioned maturity age corresponding with the chronological were selected. The players were divided into two groups: the players born in $2005(\mathrm{n}=10)$ and the players born in $2006(\mathrm{n}=10)$. The subjects underwent SEBT and IAT as well as an anthropometric measuring which was used to calculate the maturity age and the somatotype. The results were averaged with the standard deviation and compared in accordance with Cohen's $d$ to determine the substantive significance.

The results show that while the players born in 2005 are more physically fit, they lag behind the players born in 2006 as far as dynamic balance is concerned. This may be caused by the "adolescent lag" which causes many changes in the body due to the puberty spurt - these changes can be structural or functional such as e.g. the control of lower neural units by higher brain centres, lower centres operating independently, a decrease in the heart rate, and an increase in the amount of the oxygen transported.

It is only a matter of time before the adolescent adapts to the changes in their body and the performance grows linearly again. Coaches training adolescents during their pubertal development need to bear in mind that it is necessary to respect the changes occurring to their charges and to adapt their training loads to them.

\section{References}

Carter, J. E. L. (Ed.). (2002). The Heath-Carter Anthropometric Somatotype Instruction Manual. San Diego: San Diego State University. Retrieved from http://www.somatotype.org/methodology.php

Český hokej. (2017). Motorické testy mimo led, na ledě a funkční vyšetření (JLA, ELD) - 2019/20. Retrieved from https:// www.ceskyhokej.cz/treneri/motoricke-testy-mimo-led-na-lede-a-funkcni-vysetreni

Dimock, H. S. (1935). A Research in Adolescence I. Pubescence and Physical Growth. Child Development, 6(3), 177.

Espenschade, A., Dable, R. R., \& Schoendube, R. (1953). Dynamic Balance in Adolescent Boys. Research Quarterly. American Association for Health, Physical Education and Recreation, 24(3), 270-275.

Gribble, P. A., Hertel, J., \& Plisky, P. (2012). Using the Star Excursion Balance Test to Assess Dynamic Postural-Control Deficits and Outcomes in Lower Extremity Injury: A Literature and Systematic Review. Journal of Athletic Training, 47(3), 339-357.

Jones, H. E. (1946). Skeletal Maturing as Related to Strength. Child Development, 17(4), 173.

Khamis, H. J., \& Roche, A. F. (1994). Predicting adult stature without using skeletal age:The Khamis-Roche method. Pediatrics, 94(4 Pt 1), 504-507.

Lehnert, M. et al. (2014). Sportovní trénink I. Olomouc: Univerzita Palackého v Olomouci. Retrieved from https://publi.cz/ books/148/Lehnert.html

Perič, T., \& Dovalil, J. (2010). Sportovní trénink. Praha: Grada.

Ratamess, N. A. (2012). ACSM's foundations of strength training and conditioning. Philadelphia: Wolters Kluwer Health/ Lippincott Williams \& Wilkins. 
Roche, A. F., \& Davila, G. H. (1972). Late Adolescent Growth in Stature. Pediatrics, 50(6), 874.

Roche, A. F., Wainer, H., \& Thissen, D. (1975). Predicting adult stature for individuals. Basel; New York: S. Karger.

Sands, W. A., Wurth, J. J., \& Hewitt, J. K. (2012). Basics of strength and conditioning manual. Retrieved from https://www. nsca.com/contentassets/116c55d64e1343d2b264e05aaf158a91/basics_of_strength_and_conditioning_manual.pdf Shanmugam, C., \& Maffulli, N. (2008). Sports injuries in children. British Medical Bulletin, 86(1), 33-57.

Sugden, D., \& Wade, M. G. (2013). Typical and atypical motor development. London: Mac Keith Press.

Tanner, J. M. (1990). Foetus into man: Physical growth from conception to maturity. Cambridge, Mass: Harvard University Press. 